\title{
Dilemmas in language teaching and teacher education
}

\begin{abstract}
The article analyses disappointing data concerning the status of the teaching profession and teachers' self-perceptions revealed in recent TALIS, EURYDICE and EUROSTAT reports. Reasons for teachers' difficulties are then analysed vis-à-vis criteria for the evaluation of quality in education. Emphasis is given to decision-making processes and the type of dilemmas encountered by teacher trainers working in the academic context and foreign language teachers employed in school systems of EU member states. Implications for educational policies of the future are sought and an attempt is made to examine the role of enabling institutions such as the Council of Europe and the European Centre for Modern Languages in Graz.
\end{abstract}

KEYWORDS: language education; foreign language teaching; pre-service teacher education; language teachers' dilemmas; quality in education; barriers; enabling institutions.

\section{INTRODUCTION}

The teaching profession today is clearly in need of support. TALIS - The Teaching and Learning International Survey conducted by the Organisation for Economic Cooperation and Development (OECD) on a sample of 55,000 teachers employed in 3,300 schools of 19 EU member states - reveals that $80 \%$ of teachers in Europe feel undervalued and $30 \%$ of school leaders across the EU agree with that assessment (TALIS 2013). The percentage of more optimistically minded teachers who believe their profession is valued does not exceed $60 \%$, though perceptions in particular member states differ considerably with e.g. 59\% in France, $49 \%$ in Cyprus, but less than 10\% in Spain 
and Croatia, while in Sweden, France and Slovakia the share of teachers with positive feelings about the role of their profession in society drops to $5 \%$. In Poland the percentage of teachers who consider their profession to be underestimated is close to the EU average $(81 \%)$. The report states that 'although an average of 7 out of 10 teachers in the EU maintain that the advantages of being a teacher outweigh the disadvantages, the status of the profession is perceived as particularly low' (TALIS 2013: 14).

The European Union report based on TALIS and enriched by data collected by EURYDICE and EUROSTAT on a sample of 2 million teachers working in lower secondary education adds that teachers feel overburdened and unsupported. Their perceptions are confirmed and negative feelings justified by the fact that too many young people ( $12 \%$ on average, but as many as $22.6 \%$ of foreign-born students) drop out, leaving schools and vocational training before completing their education (European Commission 2014a: 9).

All of these facts are cause for concern. Therefore, it seems worthwhile to look more closely at difficulties teachers encounter in their work, types of conflicts they have to face, decisions involved and barriers encountered in the process.

In the present text I intend:

- to define the concepts of difficulty and dilemma

- to analyze criteria for the evaluation of quality in education

- to discuss teacher trainers' dilemmas arising in the process of preservice teacher education

- to discuss dilemmas faced by active teachers in primary and secondary schools and

- to reflect on the usefulness of these dilemmas in research and teacher development.

\section{TERMINOLOGY AND TYPOLOGIES USED}

The term 'difficulty' is here used to refer to an obstacle which hinders planned actions to be undertaken, while the term "dilemma" will be used to denote situations in which choice is to be made between

- conflicting expectations

- conflicting or competing values or

- two courses of action (Tillema 1997; Tillema / Kremer-Hayon 2005).

In the context of difficulty, a dilemma may also reflect a hiatus between the teacher's convictions and the course of action he or she decided to undertake. 
Therefore, not every difficulty can be treated as a dilemma, yet every dilemma is a form of difficulty.

In research on teachers' dilemmas the following distinctions have been made, i.e.

- contextual dilemmas, i.e. dilemmas rooted in the organization of education and its legal foundations

- ethical dilemmas arising on an everyday basis in the life of schools and

- teaching dilemmas, i.e. those connected with planning, managing, and conducting lessons as well as those connected with assessment and out-of-school activities (Colnerud 2006; Shapira-Lishchinsky 2011).

\section{TEACHER TRAINERS' DILEMMAS - THE HIGHER EDUCATION CONTEXT}

Academic teachers functioning as teacher trainers encounter numerous difficulties in ensuring high quality of pre-service teacher education and face dilemmas that result from conflicting values and expectations related to the organization and content of qualification programs.

What guides their efforts is a set of requirements for measuring quality in tertiary institutions. Several sets are available; the one presented below contains eight criteria, i.e.

- excellence

- fitness of and for purpose

- compliance with standards

- compliance with directives / curricula

- client satisfaction

- efficiency: value for money and time

- individual enhancement

- institutional capacity for change (Kohler 2007: 65).

The first five of these criteria give rise to most serious dilemmas.

Excellence is probably the most subjective criterion in the process of evaluating the functioning of educational institutions. In the academic context excellence is linked to research and publications, though sometimes the quality of teaching is also taken into consideration and not infrequently also the engagement of students in a broad spectrum of extracurricular activities, especially those related to social work or to collaboration with schools. The dilemma here results from the incompatibility of the standard with the financial policy of the higher education area. In the academic context of state universities, funds depend on the number of students. As demographic 
trends lead to lower enrollments, it is more difficult for the training institution to allow an underachieving student to drop out. A tendency to keep the student in the system in parallel with the tendency to meet standards typically results in a variety of interventions to prevent students from leaving programs before graduation. Most, if not all of these interventions, seriously overburden the teacher, namely students are allowed to ask numerous clarification questions by mail or in person, a never-ending number of examination resits are organized to give students second, third and further chances. As a result, the teachers' workload gets dangerously increased.

Purpose of teacher educational programs, usually identified by the national education administration, tends to refocus quite frequently as exemplified by shifts back and forth from single to dual subject teaching qualification. What remains stable, however, is the university teacher training centres' natural obligation to grant BA and MA diplomas. To do so, higher education objectives need to be achieved, highly theoretical courses offered and academic standards respected. Yet today universities are obliged to guarantee employability and equip students with practical skills which would secure them a stable place and, if possible, an attractive position in the labour market. Both objectives are difficult to attain simultaneously in a set period. The dilemma connected with which objective to prioritize is difficult for academic teachers to solve. The typical solution favours competitive advantage in the labour market and inclines teacher trainers to focus on teaching languages for occupational purposes, mainly the language of business communication. Today the choice raises the probability of success in the labour market right after graduation. Yet in an era of professional mobility, in the course of their careers graduates will undergo numerous changes of professions, countries and institutions, so the limited option of skills development in college education, though perhaps profitable in the short run, may prove to be restrictive in the broader time perspective. Moreover, this choice promotes pragmatisation of academic education, a tendency not necessarily promising for future innovation and creativity of university graduates once they enter the teaching profession.

As for standards - universities enjoying the right to offer certificates of qualifications for the teaching profession along with their BA and MA diplomas are obliged to offer a minimum of 270 contact hours of preparation courses as well as organize 150 hours of teaching practice to be supervised by the tertiary education institution. Extra cost of all those hours means either much higher expenses of state universities, institutions with permanent financial problems, or a significant increase in fees in the private ones. Higher fees are likely to discourage potential candidates for the teaching profession, therefore the only way to reduce costs is to treat teacher training 
courses flexibly, merging them with the academic ones which are indispensable to maintain the philological standard legitimizing the granting of BA and MA diplomas in the field. This, unfortunately, does not contribute to high standards for either the academic or the teacher training track.

Compliance with curricula is a criterion tightly connected with fitness for purpose. Teacher education in Poland, for example, preparing graduates to function in the Polish school system needs to be based on a detailed analysis of the Polish core curriculum, authoring syllabus documents and teaching materials used. Yet internalization of higher education, a phenomenon of high academic and cultural value, makes it extremely difficult to concentrate on one educational system's intricacies when the group is composed of large numbers of foreign students from various parts of the world, coming either within the frames of ERASMUS mobility programs or as paying students. The dilemma is how to simultaneously provide precise training for the national context and offer broad perspective on general issues of language teaching for increasing numbers of foreign students. The value of intercultural contacts is balanced out by insufficient preparation for the specificity of the national educational context. The typical way out of this dilemma, selected by most of the academic teacher trainers, is to provide general content in class and leave the analysis of the local context for individual study.

Confusion and lack of clarity accompany attempts to analyze the criterion of client satisfaction. In corporate contexts and in industry the primary client is usually the one who pays for the service, while a consumer of the service who is not necessarily the payer is considered to be a secondary client (Heyworth 2013: 284). The problem with the educational setting of in-service teacher training lies in identifying who in fact is a client. Is it the payer - the institution financing education? Is it the beneficiary? But who is the beneficiary - the direct user, i.e. the trainee? The indirect user - the future employer? The institution of employment, which is not at all the same as the person of the employer? The country whose educational system will get considerably improved if the quality of pre-service teacher education rises? The accreditation committee?

If, however, students are considered clients and it is their satisfaction that is crucial for the quality of education, a new dilemma arises. The Polish teacher qualification standard allows BA graduates to teach in primary schools only and MA graduates to teach in secondary ones. With initial education treated as a separate school level, teacher training courses in BA programs should be oriented toward the age group of 10-12 and MA programs toward the age group of 13-19. Yet students, as early as in the course of their studies, often teach in language schools, corporate contexts or else engage in private tuition working with students of various ages. It is understandable 
that they openly express the need to learn methodologies of teaching groups other than the government-set standard. Teacher trainers, therefore, face another dilemma: to give priority to student satisfaction or to the ministerial requirement. Most of them, afraid to endanger their students' qualifications and at the same time ready to satisfy their trainees' needs, decide to overload curricula even more and, in consequence, overburden themselves trying to balance both sides.

\section{LANGUAGE TEACHERS' DILEMMAS - THE SCHOOL CONTEXT}

Dilemmas of schoolteachers and of language teachers in particular have been investigated within the more general frames of research on professional stress and burnout (Maslach / Leiter 1997): in the Netherlands by KremerHayon and Tilemma (2002) and in Poland by Grzegorzewska (2006), Werbińska (2009), Pyżalski and Merecz (2010) and Pitura (2012), to mention just a few. Interesting contextual data on teachers and teaching were also collected in the course of the Teaching and Learning Survey - TALIS by Piwowarski and Krawczyk in the Polish subsample (2009). More research, however, is certainly needed (Piechurska-Kuciel 2011).

The main source of dilemmas lies in numerous and conflicting expectations vis-à-vis the teaching profession: the national core curriculum formulates ambitious and not always realistic objectives, school administration is interested in schools' ranking positions, learners expect attractive classes and parents, often absent or overworked, count on the school's reputation and its contribution to skills and competences of their children, but many also hope to be able to delegate parental upbringing and socialization duties to schoolteachers.

Another group of dilemmas spring from a considerable degree of uncertainty as to the actual role played by teachers and their contribution to the learners' educational achievement. SurveyLang - First European Survey on Language Competences, the final report on the research conducted on a sample of 50,000 15-year-olds from 16 school systems of the European Union member states (SurveyLang 2012), offers an informative index of family living standards, i.e. HOMEPOS ( home possessions), which shows a high correlation with scores of teenagers achieving B1 levels (0.44) and a very low one with outcomes of those achieving A1 (0.15). These values demonstrate that the impact of contextual variables may be more significant than that of school instruction. In addition, the Polish report on the level of speaking skills states that the Economic, Social and Cultural Status index (the socalled ESCS) shows an average score of 123 points in the top ESCS group of 
students and an average of 102.3 points in the bottom group - a difference which in terms of average linguistic progress is equivalent to more than three years of learning (IBE 2015:57). The role of school instruction is, therefore, not always clear from the point of view of teachers themselves, the more so as test scores of their students are often taken by the authorities as a measure of the teacher's professionalism. Although it has been demonstrated on more than one million pupils that school learners assigned to High-Value Added teachers are more likely to complete their tertiary education and earn higher salaries (Chetty et al. 2013a, 2013b), the effects are longterm and the correlation cannot be easily reversed. Therefore, it is not at all justified to treat every teacher of a high-achiever as an excellent professional or to accuse the teacher of a low-achiever of insufficient didactic skills.

Research data on other variables impacting language proficiency are confusing as well. Although SurveyLang confirms plenty of routine beliefs of the teaching profession, it also undermines quite a number of them. For instance, research has found no correlation between test results and the use of new technologies either in preparing or conducting lessons. Negative correlation has been found between test scores and the use of new technologies at home, the amount of time spent on homework assignments and even the amount of time spent by the teacher on preparing students for tests (SurveyLang 2012).

Moreover, schoolteachers suffer from the same uncertainty as academic teachers and teacher trainers, therefore the same questions are asked: Who is the client? The pupil? His/her parents? School administration?

If school learners are considered to be school's main customers, an important question is whether to orient teaching toward short-term goals of learner satisfaction or to strive for long-term educational aims which do not always promise immediate attraction or absence of difficulty. Short-term goals of learner satisfaction call for various forms of 'edutainment', mainly based on 'gamification' and competitive classroom activities, while longterm objectives invite learner autonomy, responsibility, reflection and effort (Jiang 2011).

If school administration is considered to be school's main customer, client satisfaction must be based on explicit standards: accreditation, examinations, certification and ranking, but also on set procedures, e.g. planning lessons ahead for the whole term as the school administration bureaucratically requires the teacher to have a full agenda pre-prepared before the first encounter with a group of students. This often clashes with implicit standards functioning in a given educational institution which on the one hand require its positive self-presentation (White et al. 2008), but on the other call for individualization and responsibility of the teacher who ought to react to 
students' feedback. Meeting implicit standards, the teacher decides to spend more time on parts of the material more difficult for students and move forward at a quicker rate if students find a given portion of the content relatively easy - and does so even despite the pre-prepared agenda.

One dilemma most often admitted by teachers is whether to bend under various types of pressures and thus avoid problems or follow their own judgment and in consequence face conflicts. Pressure comes more and more frequently from parents who try to convince the teacher that their child deserves better grades or more lenient treatment and - if their pressure remains insufficient - complain to authorities of a higher level, e.g. local boards of education or ministries in order to get their way - a phenomenon sometimes referred to by teachers as parentocracy. Another type of pressure comes from school principals who are interested in safe statistics and conflict prevention and, therefore, request teachers to change their grading decisions (Werbińska 2009b). Pressure also comes from regional authorities whose attention is mainly focused on academic achievement measured by external tests and reflected in the position of their schools in ranking tables, but not necessarily on the quality of the teaching process (De Heus / Diekstra 1999; Pitura 2012; Werbińska 2009a, 2009b).

Dilemmas mentioned above can be classified as didactic, connected with teaching methods and grading systems, but at the same time as ethical, i.e. related to the hierarchy of values (Mahony 2009).

Typically, ethical dilemmas (Campbell 2000; Johnson 2002) voiced by practicing teachers involve decisions

- whether to follow distributive justice or respect dry regulations

- whether to choose confidentiality over school rules in contacts with learners

- whether to remain loyal to the student breaking school rules or follow strict procedures

- whether to remain loyal to colleagues when they ignore school norms

- whether to ensure caring or formal climate

and on a more private note

- whether to give priority to the family agenda or meet educational standards (Hussu-tirri 2001; Shapiro-Lishchinsky 2011).

Teachers faced with dilemmas increasing their mental effort and adding to their cognitive load must simultaneously cope with numerous difficulties. Some are associated with insufficient equipment or technological breakdowns common in the work with new technologies appropriate for the visual generation of students. Yet other are related to problems with maintaining learners' concentration when, according to the National Center of Biotechnology Information, the average human attention span in the year 2015 does 
not exceed 8.25 seconds for infographics, though it was still at the level of 12 seconds in 2000 (Attention Span Statistics. http:/ /www.statisticbrain.com/ attention-span-statistics/). Even more difficulties have to do with the clash of partial, level and final objectives which need to be synchronized and reflected in certification procedures. Psychological problems spring from the double bind (Bateson 1972) between the obligation to function in a professional way and an expectation to be spontaneous and enthusiastic - a trap in which teachers are often caught. Management difficulties are often encountered when discipline problems arise or when extroverted students take most of the class time thus blocking the introverted ones from active participation in lesson activities. Contextual and psychopedagogical difficulties are often related to four basic areas - working conditions, external perception of the profession, authorities' attitudes and students' motivation (Rádai 2003). These difficulties, of course, are not language teaching specific and as such are shared by teachers across subject areas.

Difficulties specifically linked to the teaching of second or foreign languages include issues related to the use of the mother tongue and codeswitching at lessons of a foreign language, to the attitude toward the ratio of fluency and accuracy oriented activities often reflected in the amount and type of error correction and to ways of integrating students with special educational needs, i.e. the so-called S.E.N. students in mainstream tasks. $29 \%$ of EU teachers feel they cannot motivate their students to learn languages and in this respect Poland falls below the EU average with $40 \%$ of teachers with low self-efficacy assessment (European Commission 2014a). Some of the ways of dealing with difficulty are suggested by supervisors and some tend to be regulated by external or internal procedures. Yet most of these difficulties eventually involve decision-making which leads to the overlap of difficulties and dilemmas, thus forming a challenging working context.

When pressure becomes too high and teachers feel that the situation is constantly deteriorating, causing permanent tiredness, frustration and stress (Poraj 2009; Werbińska 2009; Sęk 2000) - individuals usually react by reducing their involvement to basic activities and moving into what is called a survival mode. They feel trapped: fearing job loss, losing hope of getting a better placement and waiting for any top-down changes that would improve their situation (Maslach / Leiter 1997). Yet innovations pushed by authorities in the form of educational reforms, new core curricula, teaching methods or materials are hard to come by.

Teachers under stress, facing professional burnout, tend to choose one of the two well-known ways used by people coping with unfriendly, if not straightforwardly hostile, systems. The first way has been described by Franz Kafka in The Trial, as Joseph K. tries to argue with the system, hoping 
to win his case by using methods and procedures inherent in this system and legally approved by its agencies. The second way has been presented by Jaroslav Hašek in his The Good Soldier - Švejk, a protagonist who has his own way of doing things using silent, seemingly foolish behavior that enables him to achieve his own objectives, though at a high cost that involves a loss in status and mental agreement to be permanently regarded as an idiot. Considering the value of the teacher's status in the educational context and its impact on power relations in the classroom (Goffman 1974; Manke 1997; Schrodt / Whitt / Truman 2007), teachers tend to choose Kafkaesque ways, however frustrating and ineffective.

\section{THE SUPPORTING ROLE OF POSITIVE PSYCHOLOGY - ENABLING INSTITUTIONS}

Positive psychology researching the phenomenon of well-being attaches importance to coping strategies which include gaining support from 'enabling people' or 'enabling institutions' (McIntyre / Mercer 2014; Sęk / Cieślak 2004).

In the case of language teachers, enabling activities recommended by positive psychologists come from job counsellors, who usually suggest the change of the workplace or at least a change in the function performed in the current one. Recommendations also include improving the communication flow between the teacher and students in the classroom, as well as between teachers and parents and among teachers working in the same school. Paradoxically, considering the backdrop of overburdening and burnout, taking on new duties is also suggested - on the condition that extra obligations are individually selected and carried out on the teacher's own terms Bottom-up innovation is here recommended which - driven by dissatisfaction - may bring reflective practice, action research, teamwork and interschool or international projects, e.g. those conducted within the frames of EU programs such as the European Language Label or eTwinning (Pitura 2012).

Positive psychology also stresses the role of enabling institutions. In many countries psychological counselling services are difficult to access and, what is more, often expensive. Professional guidance in many regions is merged with supervising institutions, which reduces their potential for offering true support. Effective enabling institution should be purely professional, autonomous and placed outside vertical power structures. They ought to offer practical assistance in the form of teaching materials, classroom activities, guides, books and articles that can be downloaded freely, 
but they should also create possibilities of face-to-face contacts in the form of seminars, conferences and workshops.

The European Centre for Modern Languages in Graz (ECML) can serve as a good example of an enabling institution for language teachers which fulfils all the requirements mentioned above. This is so, because the ECML bases its activity on the analysis of professional needs of teachers in its member states. The last survey carried out by the ECML revealed that more than $70 \%$ of member states see their teachers' greatest needs in the field of teaching foreign languages to young learners, teaching languages other than English and collaboration with teachers of other languages and other subject areas. It also revealed that more than $50 \%$ of member states confirm that their teachers need support in developing skills to use new technologies in education and to apply appropriate assessment techniques, with special emphasis given to non-test evaluation procedures (www.ecml.at).

The Centre engages teachers in international projects on current topics of vital interest to the profession, such as the use of social media in education, teaching multilingual and multicultural classrooms, language education for migrants, whole school language learning, intercomprehension, etc. (Komorowska 2013).

What is more, the Centre developed a special Training and Consultancy Programme which offers workshops for teachers in schools of various levels. Training and Consultancy responds to needs identified by local authorities of particular countries and assigned top priority by teachers in a given region. In recent years ECML Training and Consultancy focused on on-line materials for teacher development, the use of new technologies, formative and summative evaluation and testing, relating examinations to the Common European Framework of Reference and self-assessment with the use of the European Language Portfolio (www.ecml.at).

\section{CONCLUSION}

Analyzing dilemmas proves to be a useful field of research, results of which are likely to contribute to both pre- and in-service teacher development. It seems that in the field of teacher education, dilemmas function as conceptualisations which allow us access to teachers' attitudes, beliefs and decisions (Kremer-Hayon / Tillema 2002). They are also ways of promoting reflective models of teacher development in both pre- and in-service teacher education programs (Tillema / Kremer-Hayon 2005). Finally, they can support teacher professionalism as they call for the evaluation of alternative 
routes and for the selection of the variant most appropriate for a given educational context (Windschitl 2002).

To make teacher education more efficient, as positive psychology teaches us, enabling institutions and enabling activities are needed - which should come from government agendas. The governments' tasks need to be focused, as the European Union's policy guidelines explicitly state, 'on attracting, retaining and motivating teachers for better education' (European Union 2014b: 60). Otherwise, the goal of ensuring high quality of education, so strongly stressed in the Recommendations of the Council of Europe (Council of Europe 2012; Huber 2011) will be difficult to achieve.

A lot remains to be done by teacher trainers. More attention should be given to paradigms of teacher education (Komorowska 2011) and to the content of pre-service teacher training, but also to its synergies with the teaching practice and the mentoring system (Newby et al. 2007; Newby 2012). More emphasis ought to be laid on coordinating efforts on the part of teacher training institutions (Kelly / Grenfell 2004) now exchanging students within the frames of the ERASMUS program. More stress should also be given to the promotion of reflectivity, autonomy, learning to learn skills and selfstudy strategies not only among teachers but also among teacher educators themselves (Gabryś-Barker 2012; Loughran / Russell 2002; Samparas 2002).

Successive generations of teachers have faced various types of dilemmas since time immemorial and have been informed of them in the course of their formal education since 1685 when the first teacher training programme was launched in Reims by St. Jean-Baptiste de la Salle. Today they are encouraged to reflect on such dilemmas and make their own informed choices, although - as Amos Oz puts it in an interview conducted by Sławomir Sierakowski - Każdy wybór oznacza zdradę tej drogi, której się nie wybrało Each choice means betrayal of the option which has not been selected - tr. H.K. (Oz 2015).

\section{REFERENCES}

Attention Span Statistics. Statistic Brain RSS. National Center for Biotechnology Information, U.S. National Library of Medicine, http://www.statisticbrain.com/attention-spanstatistics. Bateson, G. 1972. Steps to an Ecology of Mind. New York: Ballantine.

Colnerud, G. 2006. Teacher ethics as a research problem: syntheses achieved and new issues. Teachers and Teaching: Theory and Practice, 12, 365-385.

Campbell, E. 2000. Professional ethics in teaching: towards the development of a code of practice. Cambridge Journal of Education, 30, 203-221.

Chetty, R. / Friedman, J.N. / Rockoff, J.E. 2013a. Measuring the Impacts of Teachers I: Evaluating Bias in Teacher Value-Added Estimates. Cambridge: National Bureau of Economic Research. 
Chetty, R. / Friedman, J.N. / Rockoff, J.E. 2013b. Measuring the Impacts of Teachers II: Teacher Value-Added and Student Outcomes in Adulthood. Cambridge: National Bureau of Economic Research.

Council of Europe. Recommendation CM/Rec (2012)13 of the Committee of Ministers on Ensuring Quality Education. Strasbourg: Council of Europe.

De Heus, P. / Diekstra, R.F.W. 1999. Do teachers burn out more easily? In: Vandenberghe, R. / Huberman, A. (eds.) Understanding and Preventing Teacher Burnout. Cambridge: Cambridge University Press, 269-284.

European Commission / EACEA / EURYDICE / CEDEFOP. 2014a. Tackling Early Leaving from Education and Training in Europe. Strategies, Policies and Measures. Eurydice and Cedefop Report. Luxembourg: Publications Office of the European Union.

European Commission. 2014b. Education and Training. Monitor. 2014. Luxembourg: Publications Office of the European Union.

Gabryś-Barker, D. 2012. Reflectivity in Pre-service Teacher Education. A Survey of Theory and Practice. Katowice: Wydawnictwo Uniwersytetu Śląskiego.

Goffman, E. 1974. Frame Analysis. New York: Harper.

Grzegorzewska, M. K. 2006. Stres w zawodzie nauczyciela. Specyfika, uwarunkowania i nastęstwa. Kraków: Wydawnictwo Uniwersytetu Jagiellońskiego.

Heyworth, F. 2013. Applications of quality management for language education. Language Teaching 46, 281-315.

Huber, J. (ed.). 2011. Teacher Education for Change. Strasbourg: Council of Europe.

Husu, J. / Tirri, K. 2001. Teachers' ethical choices in sociomoral settings. Journal of Moral Education, 30 (4), 361-375.

Instytut Badań Edukacyjnych. 2015. Efekty nauczania języka angielskiego na III etapie edukacyjnym. Raport końcowy. Badania umiejętności uczenia się i nauczania języków obcych w gimnazjum. Badanie umiejętności mówienia. Warszawa: Instytut Badań Edukacyjnych.

Jiang, K. 2011.The Dangers of Gamification. Why We Shouldn't Build a Game Layer on Top of the World. June 13, 2011, http://krystlejiang.files.wordpress.com/2011/07/the-dangers-ofgamification.pdf.

Johnson, B. 2002. Values in English Language Teaching. Mahwah, NJ: Lawrence Erlbaum.

Kelly, M. / Grenfell, M. 2004. European Profile for Language Teacher Education. A Frame of Reference. Southampton: University of Southampton.

Kohler, J. 2007. The implications for governance of institutions and systems. In: Weber, L. / Dolgova-Dreyer, K. (eds.) The Legitimacy of Quality Assurance in Higher Education. Council of Europe: Strasbourg, 59-75.

Komorowska, H. 2011. Paradigms in teacher education. In: Komorowska, H. (ed.) Promoting Multilingualism. Teaching - Learning - Assessment. Warszawa: FRSE, 13-38.

Komorowska, H. 2013. Empowering foreign language teachers - A slogan or a chance? Insights into the work of the European Centre for Modern Languages. In: Jodłowiec, M. (ed.). Exploring the Microcosm and Macrocosm of Language Teaching and Learning. Kraków: Wydawnictwo Uniwersytetu Jagiellońskiego, 155-168.

Kremer-Hayon, L. / Tillema, H. 2002. Practising what we preach. Teacher-educators' dilemmas in promoting self-regulated learning: a cross case comparison. Teaching and Teacher Education, 18, 593-607.

Loughran, J. / Russell, T. 2002. Improving Teacher Education Practices through Self-Study. London: Routledge Falmer.

MacIntyre, P. / Mercer, S. 2014. Introducing positive psychology to SLA. Studies in Second Language Learning and Teaching, (4) 2, 153-172. 
Mahony, P. 2009. Should ought be taught? Teaching and Teacher Education, 25, 983-989.

Manke, M.P. 1997. Classroom Power Relations: Understanding Student-Teacher Interaction. Mahwah, NJ: Lawrence Erlbaum

Maslach, Ch. / Leiter, M. 1997. Truth About Burnout. How Organisations Cause Personal Stress and What to Do About It. San Francisco: Jossey Bass.

Newby, D. / Allan, R. / Fenner, A.B. / Komorowska, H. / Jones, B. / Soghikyan, K. 2007. European Portfolio for Student Teachers of Languages EPOSTL). Graz. ECML. Council of Europe Publishing.

Newby, D. (ed.). 2012. Insights into the European Portfolio for Student Teachers of Languages. Newcastle: Cambridge Scholars Publishing.

Oz, A. 2015. About Judas. Sierakowski interviews Amos Oz. Polityka 6.10.2015.

Piechurska-Kuciel, E. 2011. Foreign language teacher burnout: A research proposal. In: Pawlak, M. (ed.) Extending the Boundaries of Research on Second Language Learning and Teaching. Berlin: Springer, 211-223

Pitura, J. 2012. Adult educator development and burnout: self-management of generic competences in problem prevention. In: Heikkinen, A. / Jogi, L. / Jutte, W. /Zarifis, G. (eds.). The Futures of Adult Educator(s): Agency, Identity and Ethos. Joint Conference Proceedings, 28-35.

Piwowarski, R., Krawczyk, M. 2009. TALIS - wyniki badań 2008. Warszawa: Instytut Badań Edukacyjnych.

Poraj, G. 2009. Od pasji do frustracji. Modele psychologicznego funkcjonowania nauczycieli. Łódź: Wydawnictwo Uniwersytetu Łódzkiego.

Pyżalski, J., Merecz, D. (eds.). 2010. Psychospołeczne warunki pracy polskich nauczycieli. Pomiędzy wypaleniem a zaangażowaniem. Kraków: Impuls.

Rádai, P. (ed.). 2003. The Status of Language Educators. European Centre for Modern Languages. Council of Europe Publishing.

Schrodt, P. / Whitt, P.L. / Truman, P.D. 2007. Reconsidering the measurement of teacher power use in the college classroom. Communication Education, 56 (3), 308-332.

Sęk, H. 2000. Wypalenie zawodowe u nauczycieli. Uwarunkowania i możliwości zapobiegania. In: Sęk, H. (ed.). Wypalenie zawodowe. Przyczyny. Mechanizmy. Zapobieganie. Warszawa: Wydawnictwo Naukowe PWN, 149-165.

Sęk, H., Cieślak, R. 2004. Wsparcie społeczne - sposoby definiowania, rodzaje i źródła wsparcia, wybrane koncepcje teoretyczne. In: Sęk, H. / Cieślak, R. (eds.). Wsparcie społeczne, stres i zdrowie. Warszawa: Wydawnictwo Naukowe PWN, 11-28.

Shapiro-Lishchinsky, O. 2011. Teachers' critical incidents. Ethical dilemmas in teaching practice. Teaching and Teacher Education, 27, 648-656.

SurveyLang - First European Survey on Language Competences. Final Report. 2012, Brussels: Council of Europe.

TALIS. The Teaching and Learning International Survey. Main Findings from the Survey and Implications for Education and Training Policies in Europe. 2013. Luxembourg: Publications Office of the European Union.

Tillema, H.H. 1997. Reflective dialogue in teams: a vehicle to support belief change in student teachers, European Journal of Teacher Education, 20 (3), 283-296.

Tillema, H. / Kremer-Hayon, L. 2005. Facing dilemmas: teacher-educators' ways of constructing a pedagogy of teacher education. Teaching in Higher Education, 10, 203-217.

Werbińska, D. 2009a. Wypalenie zawodowe nauczycieli języków obcych. Teoria, zapobieganie, perspektywy badawcze. Neofilolog, 30, 85-90.

Werbińska, D. 2009b. Dylematy etyczne nauczycieli jezzyków obcych. Warszawa: Fraszka Edukacyjna. 
White, R. / Hockley, A. / Laughner, M.S. / Van der Horst, J. 2008. From Teacher to Manager. Cambridge: Cambridge University Press.

Windschitl, M. 2002. Framing constructivism in practice as the negotiations of dilemmas, Review of Educational Research, 72 (2), 131-177.

www.ecml.at 
